\title{
3D models related to the publication: An assemblage of giant aquatic snakes (Serpentes, Palaeophiidae) from the Eocene of Togo
}

\author{
Georgios L. Georgalis ${ }^{1 *}$, Guillaume Guinot ${ }^{2}$, Koffi Evenyon Kassegne³ ${ }^{3}$, Yawovi Zikpi Amoudji ${ }^{3}$, Ampah Kodjo Johnson ${ }^{3}$, \\ Henri Cappetta², Lionel Hautier² \\ ${ }^{1}$ Palaeontological Institute and Museum, University of Zurich, Karl Schmid-Strasse 4, 8006 Zurich, Switzerland \\ ${ }^{2}$ Institut des Sciences de l'Evolution de Montpellier, Université Montpellier, CNRS, IRD, Cc 064; place Eugène Bataillon, 34095 Montpellier Cedex 5 , \\ France \\ ${ }^{3}$ Département de Géologie, Faculté des Sciences, Université de Lomé, B.P. 1515 Lomé, Togo \\ *Corresponding author: georgios.georgalis@pim.uzh.ch
}

\begin{abstract}
This contribution contains the 3D models described and figured in the following publication: Georgalis, G.L., G. Guinot, K.E. Kassegne, Y.Z. Amoudji, A.K.C. Johnson, H. Cappetta and L. Hautier. 2021. An assemblage of giant aquatic snakes (Serpentes, Palaeophiidae) from the Eocene of Togo. Swiss Journal of Palaeontology 140, 20, https://doi.org/10.1186/s13358-021-00236-w
\end{abstract}

Keywords: Africa, Eocene, Palaeophis, Serpentes, vertebral anatomy

Submitted:2021-08-17, published online:2021-09-24. https://doi.org/10.18563/journal.m3.154

$\begin{array}{lc}\text { Inv nr. } & \text { Description } \\ \text { UMKPO21 } & \text { Trunk vertebra } \\ \text { UMKPO22 } & \text { Trunk vertebra } \\ \text { UMKPO23 } & \text { Trunk vertebra } \\ \text { UMKPO24 } & \text { Trunk vertebra } \\ \text { UMKPO25 } & \text { Trunk vertebra } \\ \text { UMKPO26 } & \text { Trunk vertebra } \\ \text { UMKPO27 } & \text { Trunk vertebra } \\ \text { UMKPO28 } & \text { Trunk vertebra } \\ \text { UMKPO29 } & \text { Trunk vertebra } \\ \text { UMKPO30 } & \text { Trunk vertebra } \\ \text { UMKPO31 } & \text { Trunk vertebra } \\ \text { UMKPO32 } & \text { Trunk vertebra } \\ \text { UMKPO33 } & \text { Trunk vertebra } \\ \text { UMKPO34 } & \text { Trunk vertebra } \\ \text { UMKPO35 } & \text { Trunk vertebra } \\ \text { UMKPO36 } & \text { Trunk vertebra } \\ \text { UMKPO37 } & \text { Trunk vertebra }\end{array}$

Table 1. List of models belonging to Palaeophis africanus . Collection: Institut des Sciences de l'Evolution, Université de Montpellier, France.

\section{INTRODUCTION}

We conducted micro-CT scanning in 17 vertebrae of the large aquatic snake Palaeophis africanus from the Eocene phosphate deposits of Kpogamé, Togo, and we here present their 3D surface models (Table 1 and Fig. 1).

\section{METHODS}

The vertebrae were imaged using high-resolution microtomography $(\mu \mathrm{CT})$ at the MRI platform of the Institut des Sciences de l'Evolution de Montpellier (ISEM). Image segmentation of the vertebral elements was performed on the $\mu \mathrm{CT}$ images with Avizo.Lite 2019.4 (Visualization Sciences Group) software. The
3D virtual restoration was performed with MorphoDig software (v. 1.5.3; Lebrun 2018) and the virtually restored 3D models are provided in .stl and .vtp formats.

\section{ACKNOWLEDGEMENTS}

Grant sponsor: Forschungskredit of the University of Zurich grant no. [FK-20-110], SYNTHESYS GB-TAF-6591, SYNTHESYS ES-TAF-5910 (MNCN), SYNTHESYS AT-TAF-5911 (NHMW), and SYNTHESYS HU-TAF-6145 (HNHM), all to GLG. Grant sponsor: French National Research Agency (ANR10-INBS-04, 'Investments for the future'), Labex CEMEB (ANR10-LABX-0004), NUMEV (ANR-10-LABX-0020), CNRS PICS grant (n8229424), the National Geographic Society (grant NGS72222R-20).

\section{BIBLIOGRAPHY}

Georgalis, G. L., G. Guinot, K. E. Kassegne, Y. Z. Amoudji, A. K. C. Johnson, H. Cappetta and L. Hautier. 2021. An assemblage of giant aquatic snakes (Serpentes, Palaeophiidae) from the Eocene of Togo. Swiss Journal of Palaeontology 140, 20, https://doi.org/10.1186/s13358-021-00236-w

Lebrun, R. 2018. MorphoDig, an open-source 3D freeware dedicated to biology. IPC5, Paris. 

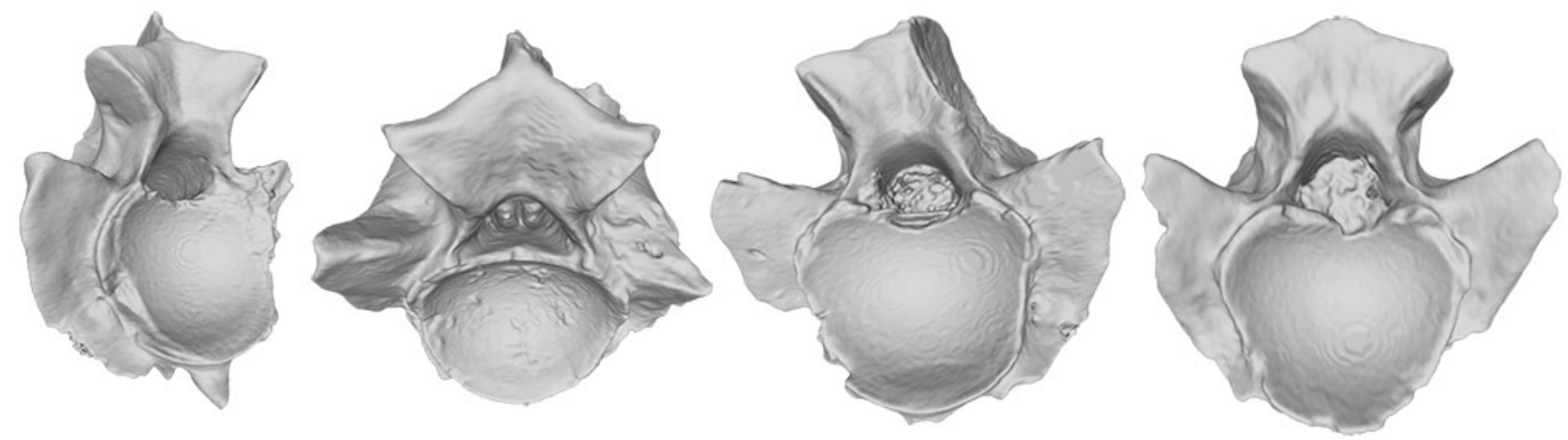

Figure 1. 3D models of four snake vertebrae of Palaeophis africanus from the Eocene of Togo (from left to right: UM KPO 22, UM KPO 32, UM KPO 21, and UM KPO 24; Université de Montpellier). From left to right, the first vertebra (UM KPO 22) is shown in right anterolateral view, the second one (UM KPO 32) in anterodorsal view, and the third (UM KPO 21) and fourth (UM KPO 24) vertebrae are shown in anterior view. Images are not to the same scale. 